\title{
Creation Process during Learning of Gifted Students: Contributions from Jean Piaget
}

\author{
Fernanda Hellen Ribeiro Piske1, Tania Stoltz ${ }^{1}$, Denise de Camargo ${ }^{2}$, \\ Carla Luciane Blum Vestena ${ }^{3}$, Jarci Maria Machado ${ }^{1}$, Samarah Perszel de Freitas ${ }^{4}$, \\ Carmen Lúcia Dias ${ }^{5}$, Joulilda dos Reis Taucei ${ }^{1}$
}

\author{
${ }^{1}$ Federal University of Paraná, Curitiba, Brazil \\ ${ }^{2}$ Tuiuti/UFPR, Curitiba, Brazil \\ ${ }^{3}$ Unicentro/UFPR, Guarapuava, Brazil \\ ${ }^{4}$ Positivo University, Curitiba, Brazil \\ ${ }^{5}$ University of Oeste Paulista, Presidente Prudente, Brazil \\ Email: nandahellen@hotmail.com
}

How to cite this paper: Piske, F. H. R., Stoltz, T., de Camargo, D., Vestena, C. L. B., Machado, J. M., de Freitas, S. P., Dias, C. L., \& Taucei, J. R. (2017). Creation Process during Learning of Gifted Students: Contributions from Jean Piaget. Creative Education, 8, 505-513.

https://doi.org/10.4236/ce.2017.84039

Received: October 25, 2016

Accepted: April 16, 2017

Published: April 21, 2017

Copyright (C) 2017 by authors and Scientific Research Publishing Inc. This work is licensed under the Creative Commons Attribution International License (CC BY 4.0).

http://creativecommons.org/licenses/by/4.0/

\begin{abstract}
This research aims to highlight the importance of Creativity in education of gifted students. Recent education focuses exclusively on the development of intellectuality; it starts at an earlier age and stimulates mainly rational thinking, sometimes leaving aside other important dimensions. For gifted children, this fact can mean the desire to escape from school for not having reason to attend it. According to Piaget's theory, the process of creation and of new discoveries is being driven by affection. The creation itself is the result of the interaction and balance between assimilation and accommodation, thus representing a new adaptation, which integrates the affective and cognitive aspect. The process of imagination, creation, invention toward new discoveries depends on how the school performs the necessary referrals for a stimulating environment of creativity. In this sense, we should always rely on the support of a team of professionals prepared to offer a quality education that aims a full human development.
\end{abstract}

\section{Keywords \\ Creation Process, Gifted Students, Piaget}

\section{Introduction}

There are challenges during the creation process of gifted students. In this sense, reflection about knowledge is necessary to overcome the simple focus on analytical thinking and also consider the emotional aspect of the development of the creation process. It is not enough simply to teach with no reflection on what is 
being taught in this sense, this article aims to highlight the importance of gifted creation process in Piaget's approach to education that prime for innovation and discovery in various areas of knowledge.

In the Brazilian educational scenario, many schools focus on teaching that prepare the individuals exclusively for the labor market. "Education referred to the instrument for the achievement of material goods is supported in the development of individualism and competition" (Stoltz, 2016: p. 192).

Recent education focuses exclusively on the development of intellectuality; it starts at an earlier age and stimulates mainly rational thinking, sometimes leaving aside other important dimensions. For gifted children, this fact can mean the desire to escape from school for not having reason to attend it. Although they are considered gifted, they may have social and emotional difficulties, these difficulties need to be attended and that refer to such important fields as their intellectual development. These children are looking for new challenges and when they find a teaching that calls their attention, most of the time, they lose the desire to learn (Stoltz, 2016; Piske, 2013a, 2013b, 2014a, 2014b, 2015, 2016; Piske, Stoltz, \& Bahia, 2015; Piske et al., 2016a, 2016b).

This search for new challenges are in line with Kneller (1978) which explains about the "creative thinking" and "thinking that is not creative"

[...] The creative thinking is innovative, exploratory, adventurous. It is impatient regarding convention, it is attracted by the unknown and undefined. Laughter and uncertainty can stimulate it. Thinking that is not creative is cautious, methodical, conservative. It absorbs the new in what is already known and it prefers to dilate the existing categories to invent new ones. (Kneller, 1978: p. 19).

In such a vast universe that is education, gifted students have special features that are not always recognized and this lack of recognition of their difficulties in different spheres of development can prevent them from having access to a service that will attend their special educational needs (Taucei, Stoltz, \& Gabardo, 2015). Ourofino \& Guimarães (2007: p. 49) express:

Given the variety of presented features and heterogeneous universe of traits that individuals with high abilities/giftedness have, it is understandable that professionals, family and school find some difficulties to provide conditions that conducive to the full development of their potential. On the other hand, we cannot ignore that gifted individuals should be understood in their entirety and that they receive all kinds of support for demonstration and expanding of their abilities. Whereas in addition to specialized service, it is necessary to recognize that these individuals keep human potential capable of bringing advances and benefits for their nations and to humanity.

Gifted students often are tired of experiencing the same repetitive lessons and sometimes they do not have perspective of change this way they may feel frustrated with the proposed education. 
A quality education, which does not reduce the knowledge to simple reproduction requires an effective work with development of potential and talents, allowing forms to work with creativity and research in various areas of knowledge to give support to the various questions of gifted students who have not got answers to their questions.

These children are curious and they look for challenges, they need to be encouraged by the school to develop their high abilities related to (s) your (s) area (s) of interest (Besançon \& Lubart, 2008; Peterson, 2014; Piechowski, 2014; Pfeiffer, 2016; Bahia, 2016; Kane, 2016; Gross, 2016; Alencar, 2014; Alencar, Braga, \& Marinho, 2016; Piske, Stoltz, \& Bahia, 2015; Piske et al., 2016a, 2016b; Machado, 2013, among other studies).

From the creativity, the desire to learn flourishes and develops in the pursuit of expanding knowledge. For Stoltz (2016), creativity can be defined as a process that takes place over time, rather than a static characteristic of individuals or certain inventive products; the creative product is new; it is related to innovation and not just the methods that reduce knowledge to a simple repetitive learning, "the creative product emerges from the combination of elements of a lower level that combine in complex systems. What is created are the combinations in complex systems" (Stoltz, 2016: p. 191).

It is interesting what Gloton (1987) calls "convergent thinking" and "divergent thinking".

Convergent thinking is used when the problem requires immediate and single solution, very structured, containing accurate data. [...] It is a kind of conformist thinking, prudent, rigorous but narrow. It is the way to act of intelligence with information, the memory etc. Divergent thinking seeks all possible solutions and prefers the originality than to conform with ready answers (Gloton, 1987: pp. 84-85).

According to Gloton (1987: p. 85), "[...] we should think about a pedagogy of difference 'to avoid blocking the creativity." In this sense, it is possible to affirm that there is no work that is really enjoyable without the existence of creativity. It is important to innovate in order to obtain sufficient results regarding the education that prime the development of creative potential.

However, nowadays, the concentration in divergent thinking, by focusing primarily cognitive aspects, proves insufficient when creativity is understood in a multidimensional perspective that considers the emotional and affective aspects with cognitive aspects (Nakano \& Zaia, 2012).

\section{The Creation Process from Piaget}

In education, creating is not always possible, but it is essential. It is necessary to give opportunities to students to create their solutions to solve problems during the classes, students should learn how to make their invention and discovery of something new. The act of creating and innovating becomes fundamental in teaching at the time where there is a perception that there is no reason in re- 
peating several times the same content that has already been taught during learning (Piske, 2015, 2016).

Therefore, the process of creation is crucial to the development of potentials and talents. Stoltz (2007), Piske \& Stoltz (2012) affirms that, according to Piaget's theory $(1932 / 1977,1936)$, the creation process is stimulated by affection, but it is the development of intelligence that will determine the new creations (Piaget, 1975, 1977a, 1977b, 1978). However, Piaget does not study the differences between abilities and intellectual abilities of each human being, but the general cognitive development of the species. The global development happens in stages and it is influenced by several factors (Gardner, 1998).

Stoltz (2007), Piske \& Stoltz (2012), Piske, Stoltz \& Bahia (2015) point out that for Piaget affectivity is related to feelings and in particular to the emotions, and it interferes in the intelligence operations when it stimulates or disturbs an individual, leading him/her to accelerations or delays in the development.

According to Piaget (1954, 1964, 1974a, 1974b) the construction of affectivity and intelligence occur in parallel, that is, the cognitive and affective aspects of action "are at the same time irreducible, inseparable and complementary" (Piaget et al., 1974). The first consists in structuring the action and the second in its energetics (Stoltz, 2007; Piske \& Stoltz, 2012).

For Piaget, intelligence is constructed by progressive structures or successive forms of equilibrium "that marks the differences or oppositions from one level of conduct to the other, from the elementary behaviors of infancy to adolescence" (1969: p. 13). Therefore, variable structures will be "forms of organization of mental activity, in a double aspect: motor or intellectual, on the one hand and affective on the other, with its two individual and social dimensions (interindividual)" (p. 13). Therefore, regarding affectivity, there are feelings intraindividual and interindividual.

Intraindividual feelings are related to all kinds of actions: emotions, instinctive tendencies, pleasures, perceptions, feelings of success or failure, etc. While interindividual feelings correspond to the personal interactions that are manifested by intuitive affection, which are expressed by elementary social feelings, with the onset of moral sentiments; normative affections, in which stem from autonomous moral sentiments, with the intervention of the will and progression, ideological feelings from the formal operations in which interindividual feelings complemented with feelings involving collective ideals (Stoltz, 2007, 2013; Piske \& Stoltz, 2012).

According to understanding of Stoltz (2013), Piaget (1981a, 1981b, 1985) points out that the process of adaptation or creation is the result of an interaction that is not located neither in the individual and nor in the world, this process it is between both of them, in the interaction. The interaction that leads to the creation in reality is a process deeply related to the lived experience (Stoltz et al., 2015).

Stoltz \& Parrat-Dayan (2012), Stoltz et al. (2015) explain that, according to Piaget, the creative process of adaptation is related to the balance between two 
mechanisms: assimilation and accommodation. In Piaget's theory, assimilation is explained by the incorporation of new data to existing schemes and structures. Then, when we refer to creating something new, first we mention the assimilation process. However, if we were not only with the assimilation for assimilation respect to the subject rather than the subject to know.

However, if we highlight only the importance of assimilation we can never move forward because the assimilation is related to the individual rather than to the object that we can know.

Stoltz (2013), points out that assimilation establishes first a necessary moment, but the evolution only happens from the balance between assimilation and accommodation. The accommodation is the adjustment movement of the individual to the new object that we can know.

This adjustment is progressive and requires a previous mechanism of assimilation because it is precisely from the conflict lived internally by the individual between what he/she knows and what he/she does not know that emerges the possibility of discovering something new. "The 'new' is the result, of the interaction and balance between assimilation and accommodation, thus representing a new adaptation" (Stoltz \& Parrat-Dayan, 2012: p. 173).

Stoltz (2013) explains that for Piaget, cognition and creativity are integrated with how to do, to feel and think. It is possible to affirm that the development of creativity encompasses a process called reflective abstraction, it is a moment of awareness of where there is first a movement to a higher plan, a reflection of the action plan for the representation plan, so there may be a process of reconstruction, enrichment, understanding and implementation to higher levels of abstraction.

The creation process is present in all cognitive activities of the individual. Stoltz (2007), Piske \& Stoltz (2012), Stoltz (2013), Stoltz \& Parrat-Dayan (2012) explain that, in Piaget's view, the creation is linked to all construction processes, stadiums and human development in its entirety.

\section{Educational Measures That Contribute to the Process of Creation and Development of Creativity}

There are some factors that can contribute to a quality education that aims to develop potentials and talents. The teaching staff can be based on these factors for their classes become more creative and interesting. Among them, Alencar, Braga \& Marine (2016) highlight:

- Create an environment of respect and mutual acceptance, where students can share, develop and learn as much from each other.

- Allow time for the students to think and develop their creative ideas, because not always a creative idea emerges instantly.

- Oportunize students to make questions, formulate and test hypotheses, disagree, propose alternative interpretations, evaluate critically facts, concepts, principles and ideas.

- Highlight what each student has to offer, informing every student about their 
strengths in their area of expertise.

- Diversify teaching procedures used in the classroom.

- Propose tasks that are interesting and meaningful to students.

- Allow students to follow the various stages of the creative process, exploring and analyzing the different aspects of a problem at first, followed by readings, discussions, formulations of different possibilities and critical analysis of the different proposed solutions (Alencar, Braga, \& Marine, 2016: p. 67).

There are several ways to instigate creativity and stimulate the creation process during the educational practices of the teaching staff. It can be exemplified by interactive teaching practices with students working together in pairs or groups, so that knowledge is shared between them by stimulating creative expression (Taucei, Stoltz, \& Gabardo, 2015). Therefore, it is important that teachers keep in mind that the more daring and innovate is their teaching, more their students can express different ways of learning and solving the proposed activities.

\section{Conclusions}

In conclusion, according to Piaget's theory, the process of creation and of new discoveries is being driven by affection. The creation itself is the result of the interaction and balance between assimilation and accommodation, thus representing a new adaptation, which integrates the affective and cognitive aspect.

For Stoltz \& Parrat-Dayan (2012), the child should invent itself through his/ her actions real objects. These authors explain that according to Piaget, the purpose of education is to learn how to invent. "The work articulated between creative imagination and rationality in the educational field is justified by differentiation that is present in creation, it is central to the development aimed at the conservation and innovation" (Stoltz \& Parrat-Dayan, 2012: p. 178).

Piske (2016), Stoltz (2016) point out that the process of imagination, creation, invention toward new discoveries depends on how the school performs the necessary referrals for a stimulating environment of creativity. In this sense, we should always rely on the support of a team of professionals prepared to offer a quality education that aims a full human development.

\section{References}

Alencar, E. M. L. S. (2014). Ajustamento Emocional e Social do Superdotado: Fatores Correlatos. In F. H. R. Piske, J. M. Machado, S. Bahia, \& T. Stoltz (Orgs.), Altas habilidades/Superdotação (AH/SD): Criatividade e emoção [Giftedness: Creativity and Emotion] (pp. 149-162). Curitiba: Juruá.

Alencar, E. M. L. S., Braga, N. P., \& Marinho, C. D. (2016). Como desenvolver o potencial criador: Um guia para a liberação da criatividade em sala de aula. Petrópolis, RJ: Vozes.

Bahia, S. (2016). Criatividade na avaliação e intervenção na sobredotação. In F. H. R. Piske, T. Stoltz, J. M. Machado, \& S. Bahia (Orgs.), Altas habilidades/Superdotação (AH/SD) e Criatividade: Identificação e Atendimento [Giftedness and Creativity: Identification and Specialized Service] (pp. 145-164). Curitiba: Juruá.

Besançon, M., \& Lubart, T. (2008). Individual Differences in the Development of Creative 
Competencies in School Children. Learning and Individual Differences, 18, 381-389.

Gardner, H. (1998). Inteligências múltiplas: A teoria na prática [Multiple Intelligences: Theory in Practice]. Porto Alegre: Artes Médicas.

Gloton, R. (1987). A actividade criadora na criança (4. ed.). Casterman: Estampa.

Gross, M. U. M. (2016). DevelopingPrograms for Gifted and Talented Students. In F. H. R. Piske, T. Stoltz, J. M. Machado, \& S. Bahia (Orgs.), Altas habilidades/Superdotação (AH/SD) e Criatividade: Identificação e Atendimento [Giftedness and Creativity: Identification and Specialized Service] (pp. 61-75). Curitiba: Juruá.

Kane, M. (2016). Gifted Learning Communities: Effective Teachers at Work. In F. H. R. Piske, T. Stoltz, J. M. Machado, \& S. Bahia (Orgs.), Altas habilidades/Superdotação (AH/SD) e Criatividade: Identificação e Atendimento [Giftedness and Creativity: Identification and Specialized Service] (pp. 77-94). Curitiba: Juruá.

Kneller, G. F. (1978). Arte e ciência da criatividade (5. ed.). São Paulo: IBRASA.

Machado, J. M. (2013). Habilidades cognitivas e metacognitivas do aluno com altas habilidades/superdotação na resolução de problemas de matemática. Tese (Doutorado em Educação), Curitiba: Universidade Federal do Paraná.

Nakano, T. C., \& Zaia, P. (2012). Criatividade e Inteligência Emocional em Crianças: Um Estudo Relacional. PSICO, 43, 388-399.

http://revistaseletronicas.pucrs.br/fo/ojs/index.php/revistapsico/article/view/10608/824 $\underline{0}$

Ourofino, V. T. A. T., \& Guimarães, T. G. (2007). Características intelectuais, emocionais e sociais do aluno com Altas Habilidades/Superdotação. In D. S. Fleith (Org.), $A$ construção de práticas educacionais para alunos com Altas Habilidades/Superdotação (pp. 53-65). Brasília, DF: Ministério da Educação, Secretaria de Educação Especial.

Peterson, J. (2014). Paying Attention to the Whole Gifted Child: Why, When, and How to Focus on Social and Emotional Development. In F. H. R. Piske, J. M. Machado, S. Bahia, \& T. Stoltz (Orgs.), Altas Habilidades/Superdotação (AH/SD): Criatividade e emoção [Giftedness: Creativity and Emotion] (pp. 45-65). Curitiba: Juruá.

Pfeiffer, S. (2016). Leading Edge Perspectives on Gifted Assessment. In F. H. R. Piske, T. Stoltz, J. M. Machado, \& S. Bahia (Orgs.), Altas habilidades/Superdotação (AH/SD) e Criatividade: Identificação e Atendimento [Giftedness and Creativity: Identification and Specialized Service] (pp. 95-122). Curitiba: Juruá.

Piaget, J. (1932/1977). O julgamento moral na criança. São Paulo: Mestre Jou.

Piaget, J. (1936). La naissance de l'intelligence chez l'enfant. Neuchâtel: Delachaux et Niestlé.

Piaget, J. (1954). Les relations entre l' affectivité et l'intelligence dans le developpment mental de l'enfant. Boulletin de Psychologie. Paris, VII, No. 3-4, 143-150; No. 9-10, 522-535; No. 12, 690-701.

Piaget, J. (1964). Cognitive Development in Children: Development and Learning. Journal of Research in Science Teaching, 2, 176-186.

https://doi.org/10.1002/tea.3660020306

Piaget, J. (1974a). La prise de conscience. Paris: PUF.

Piaget, J. (1974b). Réussir et comprendre. Paris: PUF.

Piaget, J. (1975). L'équilibration des structures cognitives: Problème central du développement. Paris: PUF.

Piaget, J. (1977a). Recherches sur l'abstraction réfléchissante. EEG34. Paris: PUF.

Piaget, J. (1977b). Recherches sur l'abstraction réfléchissante. L'abstraction de l'ordreet dês relations spatiales. EEG35. Paris: PUF. 
Piaget, J. (1978). A formação do símbolo na criança: Imitação, jogo, sonho, imagem e representação (3. ed.). Rio de Janeiro: Zahar.

Piaget, J. (1981a). Creativity. In: J. M. Gallagher, \& D. K. Reid (Eds.), The Learning Theory of Piaget and Inhelder (Appendices B, pp. 221-229). Monterey, CA: Brooks/ Cole.

Piaget, J. (1981b). L'évolution Le possible et le nécessaire: Des possibles chez l'enfant. Paris: PUF.

Piaget, J. (1985). Criatividade. In M. S. Vasconcelos (Org.), Criatividade: Psicologia, educação e conhecimento do novo. São Paulo: Moderna.

Piechowski, M. M. (2014). Identity. In F. H. R. Piske, J. M. Machado, S. Bahia, \& T. Stoltz (Orgs.), Altas Habilidades/Superdotação (AH/SD): Criatividade e emoção [Giftedness: Creativity and Emotion] (pp. 97-114). Curitiba: Juruá.

Piske, F. H. R. (2013a). O desenvolvimento socioemocional de alunos com altas habilidades/superdotação (AH/SD) no contexto escolar: Contribuições a partir de Vygotsky. Mestrado em Educação Dissertação, Curitiba: Universidade Federal do Paraná.

Piske, F. H. R. (2013b). Criatividade no Processo de Aprendizagem de Superdotados. In III Seminário Internacional de Educação de Pinhais (pp. 1-12).

Piske, F. H. R. (2014a). O desafio de promover práticas educacionais para atender a alunos superdotados. In IV Seminário Internacional de Educação de Pinhais (pp. 1-11).

Piske, F. H. R. (2014b). Criatividade e inovação na educação de superdotados. In F. H. R. Piske, J. M. Machado, S. Bahia, \& T. Stoltz (Orgs.), Altas Habilidades/Superdotação (AH/SD): Criatividade e emoção [Giftedness: Creativity and Emotion] (pp. 265-276). Curitiba: Juruá.

Piske, F. H. R. (2015). Aluno (a) com altas habilidades/superdotação (AH/SD): Quem é essa criança? In IV Seminário Internacional de Educação de Pinhais (pp. 1-12).

Piske, F. H. R. (2016). Alunos com Altas Habilidades/Superdotação (AH/SD): Como identificá-los? In F. H. R. Piske, T. Stoltz, J. M. Machado, \& S. Bahia (Orgs.), Altas Habilidades/Superdotação (AH/SD) e Criatividade: Identificação e Atendimento [Giftedness and Creativity: Identification and Specialized Servisse] (pp. 249-260). Curitiba: Juruá.

Piske, F. H. R., \& Stoltz, T. (2012). O desenvolvimento afetivo de alunos superdotados: uma contribuição a partir de Piaget. Schème: Revista Eletrônica de Psicologia e Epistemologia Genéticas, 4, 149-166.

http://www2.marilia.unesp.br/revistas/index.php/scheme/article/view/2400/1953

Piske, F. H. R., Stoltz, T., \& Bahia, S. (2015). Percepções de famílias de superdotados sobre o processo de ensino-aprendizagem: Um olhar a partir de Piaget. Schème: Revista Eletrônica de Psicologia e Epistemologia Genéticas, 7, 78-97.

http://www2.marilia.unesp.br/revistas/index.php/scheme/article/view/5781/3952

Piske, F. H. R., Stoltz, T., Machado, J. M., Vestena, C. L. B., Oliveira, C. S., Freitas, S. P., \& Lopes, C. L. (2016a). Working with Creativity of Gifted Students through Ludic Teaching. Creative Education, 7, 1641-1647. http://file.scirp.org/pdf/CE_2016072718141930.pdf

Piske, F. H. R., Stoltz, T., Vestena, C. L. B., Freitas, S. P., Valentim, B. F. B., Oliveira, C. S., Barby, A. A. O. M., \& Lopes, C. L. (2016b). Barriers to Creativity, Identification and Inclusion of Gifted Student. Creative Education, 7, 1899-1905.

http://file.scirp.org/pdf/CE_2016082517133903.pdf

Stoltz, T. (2007). O problema das relações entre afetividade e inteligência. In N. F. Dinis, \& L. M. Bertucci, Múltiplas faces do educar: Processos de aprendizagem, educação e saúde, formação docente. Curitiba: Editora UFPR. 
Stoltz, T. (2013). Desenvolvimento cognitivo como invenção e para além da racionalidade. In F. H. R. Piske, \& S. Bahia (Orgs.), Criatividade na escola: O desenvolvimento de potencialidades, altas habilidades e talentos [Creativity at School: Development of Potentials, High Abilities and Talents] (pp. 85-95). Curitiba, Juruá.

Stoltz, T. (2016). Imaginação e Criatividade na Educação: A necessidade de outro olhar. In F. H. R. Piske, T. Stoltz, J. M. Machado, \& S. Bahia (Orgs.), Altas Habilidades/ Superdotação (AH/SD) e Criatividade: Identificação e Atendimento [Giftedness and Creativity: Identification and Specialized Service] (pp. 249-260). Curitiba: Juruá.

Stoltz, T., \& Parrat-Dayan, S. (2012). Imaginário criativo e racionalidade: Incompatibilidade ou compatibilidade? In L. C. Moreira, \& T. Stoltz (Orgs.), Altas habilidades/ superdotação, talento, dotação e educação [Giftedness, Talent and Educacion] (pp. 171-179). Curitiba: Juruá.

Stoltz, T., Piske, F. H. R., Freitas, M. F. Q., D’Aroz, M. F., \& Machado, J. M. (2015). Creativity in Gifted Education: Contributions from Vygotsky and Piaget. Creative Education, 6, 64-70. http://file.scirp.org/pdf/CE_2015011416262533.pdf https://doi.org/10.4236/ce.2015.61005

Taucei, J., Stoltz, T., \& Gabardo, C. V. (2015). Creativity and Education: Interactive Teaching Practices with a Gifted Student. Creative Education, 6, 2263-2273.

http://file.scirp.org/pdf/CE_2015121010592962.pdf

https://doi.org/10.4236/ce.2015.621234

\section{Submit or recommend next manuscript to SCIRP and we will provide best service for you:}

Accepting pre-submission inquiries through Email, Facebook, LinkedIn, Twitter, etc. A wide selection of journals (inclusive of 9 subjects, more than 200 journals)

Providing 24-hour high-quality service

User-friendly online submission system

Fair and swift peer-review system

Efficient typesetting and proofreading procedure

Display of the result of downloads and visits, as well as the number of cited articles

Maximum dissemination of your research work

Submit your manuscript at: http://papersubmission.scirp.org/

Or contact ce@scirp.org 